\title{
BECOMING THE STATE-FUNDED MADRASAH OR RETAINING AUTONOMY: THE CASE OF TWO MADRASAHS IN KELANTAN
}

\author{
Hilman Latief \\ Universitas Muhammadiyah Yogyakarta (UMY), Indonesia \\ h_latief@umy.ac.id \\ Anidah Robani \\ Universiti Teknikal Malaysia Melaka (UTeM), Malaysia \\ anidah@utem.edu.my \\ Mohd Fauzi Kamaruddin \\ Universiti Teknikal Malaysia Melaka (UTeM), Malaysia \\ mohdfauzi@utem.edu.my \\ Rozikan \\ Universitas Muhammadiyah Yogyakarta (UMY), Indonesia \\ Rozikan_08@ymail.com
}

\begin{abstract}
Malaysia witnessed the rise of Islamic education more than a centuryago, partly evidenced by the establishment of traditional Islamic education institutions called pondok or madrasah. Starting in the nineteenth century, Islamic pondok schools spread in Malaysia, founded by 'ulama (Islamic scholars) who gained financial support from the community. As time went by, many pondok, previously supported by civil society,
\end{abstract}


began to face financial difficulties because of the changing political landscape, economic situation, the death of their founders, and changes in government policy. This paper investigates the experiences of two madrasahs in the state of Kelantan in Malaysia and the strategies they have adopted to resolve their financial issues. This paper argues decisions and strategies regarding financing were influenced by several factors, including the degree of attachment felt by the current asatidz (teachers) to the history of their pondok, their desire to preserve the legacy of the madrasah founder, and the level of economic pressure they experienced. The primary choice was between relinquishing ownership to the state by becoming a state (funded) school or remaining a self-governed school with limited access to state funds.

Keywords: Madrasah, financial sustainability, civil society, state agencies.

\section{A. Introduction}

Malaysia is the second largest Muslim country in Southeast Asia. It has witnessed the development of Islamic schools for more than a century. Some schools have modernized their curriculum, education system, and facilities, while others have remained traditional by focusing on teaching Islamic subjects only (Alfurqan, 2020; R. Hashim et al., 2011). Traditional Islamic schools in Malaysia, notably in Kelantan, are called pondok, derived from the Arabic word funduq, which means "hotel" or "inn." The Malaysian pondok is equivalent to the Indonesian pesantren in Java (Hashim \& Langgulung, 2008; Steenbrink, 1986) or dayah in Aceh (Huwaida, 2015; Roche, 2012). Pondoks were established as centers of Islamic learning that provided students with a "comprehensive" Islamic education. Students learned Islam while developing 
their character. The students stayed in dormitories during their studies, frequently visiting the mosque located in the pondok complex and regularly meeting with their mentors or teachers, who also lived in the dwellings around the pondok complex.

The pondok learning system emerged in Malaysia in the nineteenth century during a period of Islamic "knowledge transmission" in Southeast Asia (Ali, 2006; Azra, 2004; Dhofier, 1990). Observers have linked the proliferation of pondok in Kelantan with Islamic scholars from Sumatra, Kedah, and Pattani (Winzeler, 2017) as well as with those from the Middle East (M. Abdullah et al., 2011). Pondok schools have distinctive features and have played a profound role in imparting Islamic values and in the Islamization process in Kelantan. For many years, Kelantan has been of particular interest to political parties in Malaysia, not only to Islamic parties such as the PAS (The Malaysian Islamic Party), through which pondok schools channel their political aspirations, but also to the UMNO, which has attempted to increase its patronage and influence in the state. Under the pressure of political parties, pondok school leaders have a choice: They must either find a way to sustain political power or give into the demands of the state by changing their militant character and reconstructing their school system (Noor, 2004, 2008; Tayeb, 2018).

Many pondok schools were founded by respected 'ulama (Islamic scholars) or Tuan Guru (Islamic teachers) to spread and preserve the Islamic mission in the regions where they resided. Highly respected by the Sultanate, the Tuan Guru's efforts to set up Islamic educational institutions were warmly received by the community. 
The establishment of pondok in Kelantan, like in other regions of Southeast Asia, such as Java and Aceh in Indonesia, Kedah in Malaysia, and Pattani in Thailand, is integrally linked to philanthropic practices, such as such as waqf (pious endowment), zakat (alms), and sadaqa (donation/voluntary giving) (Ahmad et al., 2019; Mujani et al., 2014). Waqf, family contributions, and public donations were instrumental in establishing a pondok or madrasah in a community, reflecting the importance of civil society engagement in the proliferation of Islamic educational institutions. Madrasahs received financial support from the public and the families of 'ulamas, which allowed the schools to remain autonomous and selffunded for decades.

However, soon after the respected scholars and the madrasah founders passed away, some of these schools started facing financial difficulties, precipitated by a decline in community donations, weakened civil society systems, and the expansion of state agencies. These developments negatively affected community-funded pondoks and financially autonomous Islamic educational institutions. As noted by Fazial and Bahari, "among the greatest challenges and obstacles of the pondok institutions in Malaysia to ensure that they can sustain and continue to prosper comes in terms of the lack of financing" (Fazial \& Bahari, 2018: 1905). They further explain that pondok institutions in Malaysia "tend to suffer because they only get financial resources through the Muslims' contributions like donations, infaq, zakat and waqf and do not have a systematic education system."(Fazial \& Bahari, 2018). 
This paper focuses on the experiences of Islamic private schools (madrasah) in addressing their financial difficulties, negotiating with the state, and determining their ownership status. This paper poses several questions: How are pondoks in Kelantan seeking alternative ways to overcome their financial difficulties in order to survive? In the face of looming state intervention, what are the arguments informing their decision to become state-funded schools or remain independent private schools? What are the consequences faced by pondoks or madrasahs after they decide to join or not join government schemes? To answer the above questions, we examine two schools in Kelantan: Madrasah Al-Rahmaniah Ad-Diniyah (Pondok Lubuk Tapah) in Pasir Mas, and SMA (Maahad) Darul Anuar located in Kota Bharu. We analyze how these schools have handled their financial issues and the strategies they are adapting to survive.

For this study, we adopted qualitative research methods to conduct a case study of selected pondoks. Although we investigated pondoks in Kelantan as well as in Kedah in Malaysia, only results for Kelantan pondoks, namely Madrasah Al-Rahmaniah Pondok Lubuk Tapah and SMA Darul Anuar, are reported in this paper. By examining these cases, we managed to identify the factors, processes, and relationships that determine the ability of pondoks in this region to survive and maintain their legacy. Fieldwork was conducted in Kelantan state in 2019 to explore the patterns of madrasah/pondok and how they survive and develop. Kelantan is one of the fourteen states of Malaysia. Kelantan was part of the Melaka Sultanate in the late fifteenth century and was occupied by the Japanese in the early 1940s. Although we visited several madrasah in 
Kelantan, we have chosen to focus on two of them, located in Kota Baru or Kota Baharu ("new city") and Pasir Mas District, in this paper. Kota Baru is the state capital of Kelantan, where the Sultan and Sultanah of Kelantan reside in their palaces. Pasir Mas district was originally part of Kota Bharu, but was granted political autonomy (its own local government) in 1918.

During the fieldwork, focus groups were conducted with heads of pondok and selected teachers. The interview guide was divided into six overarching themes: historical evolution of the pondok, human resources and administration, students' learning experience and achievements, strengths and weaknesses analysis, social links and impact on the community, and future projections for the school. On average, each interview lasted 47 minutes. All the interviews were audio-recorded and transcribed by the last two researchers. Informed consent was obtained from the participants through e-mail correspondence.

We administered focus groups with a maximum of 10 people from each pondok comprising the head of the pondok and selected teachers. This group of people was able to provide information on the current situation and trends in their pondok regarding the school's economic well-being and financial sustainability. The informants were also helpful in providing information on their future plans and strategies to sustain their existence. After the interview, researchers collected and analyzed all relevant data, including documents, archival records, observations, and artifacts. Subsequently, all data were organized, transcribed, and thematized in accordance with the objectives of the study. The following section discusses the analysis of interview data. Decisions 
and strategies regarding financing were influenced by several factors, including the degree of attachment felt by the current asatidz (teachers) to the history of their pondok, their desire to preserve the legacy of the madrasah founder, and the level of economic pressure they experienced.

Our observations and conversations with the Islamic teachers working in the two pondoks suggest that the economic and political shift in Kelantan, as well as the changing nature of the relationship between the state and civil society in financing Islamic education, have led these two madrasahs (Madrasah Al-Rahmaniah Pondok Lubuk Tapah and SMA Darul Anuar) to adopt different strategies to survive. The schools have had to choose between becoming a state-funded school, resulting in a loss of ownership and autonomy, or becoming a financially autonomous pondok with limited financial support and a preserved cultural legacy. In presenting our research findings, we focus on the efforts of Islamic school leaders to finance their institutions, a process which is affected in many ways by the current state funding policies in Kelantan.

\section{B. Madrasah, Politics and Financial Issues}

The dynamics surrounding Islamic schools in the Muslim world and within the communities of Muslim minority groups in particular have drawn scholars' attention. The proliferation of Islamic schools not only represents the increasing awareness among Muslims of the importance of educating the community; it also reflects the dynamics of political Islam-the efforts to spread notions of particular Islamic views, whether they be modern, traditional, conservative, liberal, or even radical- 
and denotes the deep engagement of civil society in altering the state's duties (Fathil \& Oktasari, 2017). There are different types of religious, political, and cultural orientations of Islamic educational institutions. Islamic school principals can function as "socio-religious curators" that shape the patterns of a school's religious inclinations: toward a more conservative or progressive approach. In this respect, school principals have played an instrumental role in determining whether education systems are open, inclusive, and plural or closed, exclusive, and unitary (Brooks et al., 2020).

Malaysia, Indonesia, Pakistan, Turkey, Saudi, and Egypt are countries where Islamic education proliferated with distinct models and trajectories, depending upon the nature of the states or political regimes that controlled the relationship between Islam and politics. Islamic education could not escape from the influences of transnational Islamic movements which intervened in the political dynamics of many countries (Noor et al., 2008). Likewise, geopolitical context and religious demographics determine how Islamic educational institutions gain trust from the community (Brooks, 2015). Where violent actions and religious-ethnic conflicts frequently occur or where Muslims are a religious minority, gaining confidence from the community and government become increasingly complicated.

Muslim countries have witnessed a long process of what Robert Hefner has termed "schooling Islam." The proliferation of madrasahs in the Muslim world can be seen as a means by which Muslim societies have sought to emphasize orthodoxy "through a re-focus on Islamic tradition" (Hefner, 2007: 11). For centuries, madrasahs have been the central institutions 
of civil society. Hefner further notes, "the last two centuries have been marked by the appearance of a powerfully interventionist state with educational ambitions distinct from those of the 'ulama (Hefner, 2007: 4). The presence and development of madrasahs run by the community or civil society organizations is contingent upon whether the state's constitution is secular, multireligious, or Islamic and upon whether the interests of madrasahs align with state interests (Leirvik, 2004).

It is worth emphasizing that government policies and the types of curriculum in Madrasah systems run by civil society organizations may differ from one state to another. The curriculum for madrasah can be described as "religious education for Muslims," where the objective is to foster "a nation-transcending Muslim community (umma)" (Leirvik, 2004: 224). At the same time, the curriculum can be described as religious instruction to strengthen national identity through "inclusive ways of teaching religion and values in school" (Leirvik, 2004: 224). In Singapore, for example, the curriculum of Madrasahs is generally more modern and inclusive (Steiner, 2011). The demand of Muslim communities for better Islamic education, not only in terms of facilities and curriculum but also in terms of the school's ability to adopt a modern system, can be fulfilled through state support.

Some civil society organizations in Muslim countries, represented partly by Muslim NGOs or foundations, have been successful in providing healthcare, education, and other types of welfare-oriented activities to the community. Unsurprisingly, many Muslim families prefer to enroll their children in Islamic schools, regardless of their quality. This 
situation can be seen in Egypt, Palestine, Pakistan, Afghanistan, Indonesia, and Malaysia. In many cases, Muslim NGOs, in trying to maintain autonomy and financial independence are struggling to finance their educational institutions (H Latief \& Amirrachman, 2016). Therefore, some madrasahs utilize Islamic financial schemes such as waqf and zakat to alleviate their financial burdens.

There are different models of financing education in Islamic tradition, one of which relies on Islamic philanthropic practices. Although Muslim scholars have different legal opinions on the use of zakat for education, this practice seems to be permitted by the fisabilillah portion of the distribution of zakat and is generally tolerated (Malami, 1993: 49). There are also other frameworks of educational financing that have been formulated in recent times, such as "cash waqf with blockchain" (Gazali \& Che Ismail, 2019), in practice, some Islamic educational institutions continue to face financial constraints due to lack of access to government funds or outdated fundraising systems. Studies have suggested that the emerging financial issues faced by pondok and madrasah are caused by a few different factors: lack of proper waqf administration, weakness of the waqf legal framework, and low levels of confidence in waqf management (Fazial \& Bahari, 2018). In addition to utilizing Islamic philanthropic practices, some madrasahs have attempted to foster various entrepreneurial and income-generating projects (Latief, 2012; Isbah, 2012, 2019).

In Malaysia, Islamic education institutions are included as part of the national education system. In recent times, the government has allowed civil society and religious 
organizations to set up and sustain their own education systems in accordance with the values of the organization. The government has also played a profound role in supporting private Islamic educational institutions by providing different types of financial schemes and attempting to standardize the quality of these institutions, including their curriculums, teachers, facilities, and the teaching-learning process. Once an Islamic school decides to be part of the government's financial scheme, there are some consequences: They must follow government rules that may not align with long-held pondok traditions.

In countries such as Malaysia, Indonesia, and Thailand, madrasahs and pondoks are maintained through the active involvement of civil society in educating the community (Liow, 2009; Pohl, 2006). Thousands of pondok operating in different regions have secure networks thanks to the transmission of knowledge among Islamic scholars, but they are all autonomous and have their own distinctive character developed by their founders (Zarkasyi, 2020). The founders of pondok schools usually have a strong admiration for or connection to specific respected Islamic scholars, many of whom studied in the Middle East. Some pondok leaders may have ideological, intellectual, or familial ties to these 'ulama, and they can even inherit their charisma (Arifin, 2013). Pondok schools usually rely heavily upon the reputation of their founders or current leaders. Robert L. Winzeler, who studied traditional pondoks in Malaysia in the 1970s, made the following observation: "the reputation which an individual guru possesses and the influence which he exerts depend on his acknowledged mastery of the wisdom and teachings of Islam or some of its essential aspects and upon 
his character, lifestyle and religious piety" (Winzeler, 2017: 97). In some cases, the founder's reputation is also associated with "his reputed possession of spiritual powers and the nature of his political orientation and involvement" (Winzeler, 2017: 97). In short, the reputation of Tuan Guru or the leader of a pondok determines public perception of the school. When the charismatic pondok leaders passed away, the reputation of some of the schools declined. In this respect, one observer notes:

The history of pondoks in Kelantan shows that in the 1980s and years before many pondoks died...when their respective tok gurus passed away. However, in the same period, we also see that new pondoks were established... Looking at this development, we can say that even where the mainstream did not support pondoks some pondoks in Kelantan still managed to survive. This situation shows that the demand is still there but not as high as they were previously... For the future, the survival of pondoks will depend on the management of existing pondoks and their leaders who will determine the continuation of the pondok system (L. H. Abdullah, 2011: 002197).

The reputation of the pondok leader was instrumental in strengthening the ties among pondok teachers and the supports from other parties (outsiders), not only in the past but also more recently when some Islamic schools were modernized.

The financing of Islamic schools (madrasah) in Kelantan and the other federal states of Malaysia has been under the shadow of a political rivalry between UNMO, the largest political party in Malaysia, and the Malaysia Islamic Party (PAS). The policies issued by the UMNO-led government and PAS-led government regarding Islamic education, especially in Kelantan, were vastly different, even though both political 
parties have used government aid for Islamic education to influence society's political orientation. The politics of educational assistance has affected the nature of Islamic education in Malaysia (Tayeb, 2019). As the mostimpoverished state in Malaysia, the state of Kelantan has witnessed the rise of Islamic education as an issue of substantial political interest over a period of decades.

Government agencies such as Yayasan Islam Kelantan (Kelantan Islamic Foundation) were established in the 1960s to assist pondok and madrasah with financial issues and standardize pondok quality and enrollment capacity. The purpose of these agencies was not only to ensure financial security but also to create political networks and propogate a political ideology. The party-led government could offer a large amount of financial support for a pondok that supported the party or vice versa; the government could also take over school management for a variety of reasons. In this context, Yayasan Islam Kelantan (YIK) has been central to the transformation of many community-based Islamic schools (Sekolah Agama Rakyat/SAR) in Kelantan. Founded in 1973, YIK represents the state's interest in increasing the capacity of Islamic schools. According to the YIK's official website, in 1976, the state converted six community-based Islamic schools/ madrasahs into state schools: Madrasah Muhammadiah (Kota Bharu); Madrasah Falahiah (Pasir Pekan, Tumpat); Madrasah Amir Indera Petra (Beris Kubor Besar, Bachok); Madrasah Yaakubiah (Nipah, Bachok); Madrasah Arabiah (Pasir Mas); and Madrasah Syamsul Maarif (Pulai Chondong, Machang) (http://www.yik.edu.my). 
This policy continues to this day, although not all Islamic schools that face financial difficulties surrender to government intervention. The conversion of communitybased Islamic schools into state schools in Malaysia is strongly linked to the political decisions of the central government. It was reported in 2003 that hundreds of private Islamic schools and thousands of students and teachers "would be diverted to national Islamic schools due to their dismal academic performance and anti-government activities" (Tayeb, 2019: 69). The result was that about 15,000 students and 2,000 teachers studying and working in private Islamic schools were transferred to other schools (Tayeb, 2019: 69).

The section below compares the experiences of two madrasah in Kelantan in facing a delicate situation and resolving their financial problems. Although many madrasah in Muslim countries, including Malaysia, have faced financial constraints, there are a wide variety of strategies adopted by madrasah leaders (the chairperson and teachers) to resolve these problems and forge a new future. These differences in strategy and the factors that create such differences serve as an interesting area of investigation. The cohesion among teachers, the vision of the leaders, and the relationship between the madrasah and the community appear to be the determining factors influencing whether or not the madrasah leaders decide to entrust their institution to state agencies or keep their autonomy in the face of financial hardship.

\section{Two Madrasahs and the Charismatic Founders}

This section provides a profile of two madrasahs that we have examined as case studies. It describes and discusses 
the madrasahs' historical background, the lives of their founders, and their socio-political development. As mentioned previously, some pondok/madrasah were established by famous Islamic scholars within specific domestic socioeconomic and political contexts. These contexts have in many ways shaped the madrasahs' political orientations and relationships with the government.

\section{Pondok Lubok Tapah and the Tuan Guru Haji Abdul Rahman's Legacy}

Madrasah Al-Rahmaniah Ad-Diniyah (Pondok Lubuk Tapah), is one of the oldest madrasah in Kelantan, Malaysia that remains in existence to date. It was founded in 1932 by a respected 'ulama in Kelantan, Tuan Guru Haji Abdul Rahman bin Che Wan bin Senik bin Haji Muhammad bin Lebai Abdul Latif bin Abdullah. He founded this pondok as soon as he returned from Mecca in 1931. Haji Abdul Rahman Lubok Tapah (1902-1989) was part of the second generation of 'ulamas in the $20^{\text {th }}$ century who established pondok in Pasir Mas district. The rise of pondok in Pasir Mas district cannot be detached from the esteemed 'ulama Tok Padang Jelapang, from the esteemed 'ulama Tok Padang Jelapang, who nurtured Haji Abdul Rahman bin Che Wan and other respected 'ulama in Kelantan in their cultivation of early Islamic knowledge. Young Haji Abdul Rahman was also a former student of Tok Kenali (Muhammad Yusuf bin Ahmad al-Kelantani, d. 1933), another famous 'ulama whose pupils have played instrumental roles in the spread of pondok in Kelantan, especially in Kota Bharu and Pasir Mas in the mid-20 $0^{\text {th }}$ 
century. In 1927, Haji Abdul Rahman travelled to Mecca and stayed there to study from Meccan scholars for four years (Mahmud, 2017: 189-190). Thanks to his Islamic knowledge, devotion to Islam, and endless endeavors to teach the Malay-Muslim in Kelantan, Haji Abdul Rahman was appointed as a committee member of Jamaah 'ulama Majlis Agama Islam dan Adat Istiadat Melayu Kelantan in the 1940s and remained a member until the 1950s (Mahmud, 2017: 191).

In its early stages, Pondok Lubok Tapah was very modest and had limited facilities and a small number of students. The location where the pondok was founded belonged to Haji Abdul Rahman and his family. The situation of Pondok Lubok Tapah was just like other traditional pondok in Southeast Asian regions. The founder's family endowed pieces of land, which formed the foundation of the pondok grounds. After three generations, Pondok Lupuk Tapah occupied about seven hectares of land, hosting approximately 300-400 students. The land endowed by the founder has been used for student dormitories, classes, a mosque, and a house for the founder's family. The students come from different regions in Malaysia, mainly from Kelantan. Like other pondoks, the main building in the complex is the house of the founder, which is used as an office. The pondok does not provide meals for students, so they arrange their own meals. The students usually receive groceries from their families and cook in the kitchen provided by the pondok. Some students may also buy food daily from the modest food stores set up by the local people. 
The pondok provides a semi-structured curriculum for students aged 13 to 30 years old. These students learn Arabic, fiqh (Islamic jurisprudence), Islamic theology, and ethics. Like other pondoks in Malaysia, the books of fiqh utilized in the pondok are mainly from the Shafi'ite school of thought (mazhab) and the Ash'arite theology. The pondok runs a traditional pondok system and uses learning sources in Arabic and Jawi (Malay Arabic). There is no clear distinction between what students learn in the pondok at different ages. It is common for students to learn Islam together based on their level of proficiency, not by age. Based on how long the student has lived there and the requirements_of each class, the pondok provides a semistructured curriculum for students aged 13 to 30 years old and is supported by 30 male and female teachers. The lowest level students (levels 1-4) have the "morning class" until noon, and adults and teenagers who want to learn Islam are taught in the afternoon after Dzhuhur and Maghrib prayers. Many graduates from Pondok Lubok Tapak continue studying Islam in Kolej Islam Antarbangsa Ismail Petra (KIAS) (Interview, July 2019).

Apart from educating students who came from different areas of Kelantan, Haji Abdul Rahman also taught his children, one of whom was Haji Abdullah (born 1933), who became very popular and was later known as “Tok Guru Haji Lah Lubok Tapah." Like his father, Haji Abdullah pursued his studies in Mecca for 14 years, from 1953 until 1966. Haji Abdullah is renowned as a keen follower of the Shafi'ite school of thought in fiqh but was open-minded to other madzhab. He often 
issued fatwa (legal opinions) on various topics in Islamic fiqh. His thoughts and fatwas was not always in line with the fatwas issued by Malaysian 'ulamas (Abdullah et al., 2011:338-342; Jamsari \& Zain, 2006). Tuan Guru Haji Abdullah is also known for his contribution in 'ulumul alhadith in Kelantan (Mohd. Ramli et al., 2017).

The leadership of the pondok was entrusted to Tuan Guru Haji Abdullah after his return from Mecca. Under his leadership, from 1969 to 2008, Pondok Lubok Tapah became increasingly popular among Muslim communities in Kelantan and other regions, including Thailand, Indonesia, Singapore, and Cambodia. Pondok Lubok Tapah hosted hundreds of students of different nationalities. To date, the institution has produced thousands of graduates who have become imams, lecturers, Islamic teachers, and founders of newly established pondok (Interview with a teacher, July 2019).

Pondok Lubok Tapah has also established a network with other pondoks, and it is a member of a pondok association in Kelantan known as Pusat Pembangunan Pondok (Center of Madrasah Development). Within this association, pondok representatives often share their views with other pondoks in Kelantan and discuss various topics, such as curriculum, human resources, students, and financial issues. By being a part of this association, Pondok Lubok Tapah attempts to preserve its original identity as a pondok whose values are defined by its founder. Thanks to the founder's reputation, Pondok Lubok Tapah is frequently visited by local government officials, politicians, and other respected 
'ulamas from Malaysia and overseas. It is said that 'ulama from Hadhramaut frequently visited Pondok Lubok Tapah, and in 1976, a prominent 'ulama from Indonesia, Syaikh Nuruddin al-Banjari, also came to pondok to meet the founder. Pondok Lubok Tamah is currently chaired by Tuan Guru Haji Abdullah's son, Dr. Luqman bin Haji Abdullah, currently Mufti of Wilayah Persekutuan, Malaysia and formerly a senior lecturer of Islamic Studies Academy, at University of Malaya, Malaysia.

Pondok Lubok Tapah has shown its strength of character by retaining the traditional Islamic knowledge acquired by two generations of 'ulama, the founder (Haji Abdul Rahman) and his first successor (Haji Abdullah). These two figures from Pondok Lubok Tapah were icons within the Muslim community in Kelantan and were highly influential in the region during their time. Due to their contributions to Islamic $d a^{\prime} w a$ through the traditional educational system, Haji Abdul Rahman, Haji Abdullah, and their pondok were recognized throughout Kelantan. As a result of this history, recent successors have made every effort to preserve the founders' legacy.

\section{Pondok Maahad Darul Anuar and Founder's Political Engagement}

Another case study is Maahad Darul Anuar, founded in 1965 by Haji Nik Mat Ali, known as "Tokku Mat." For many years, the founder nurtured the development of this madrasah as a traditional pondok. Maahad Darul Anuar became increasingly known when Nik Abdul Aziz, the founder's son, took over leadership 
from his father. Nik Abdul Aziz studied Islam at Darul Ulum, Deoband-India and Azhar University-Cairo for his undergraduate and master degrees, respectively, before directly engaging with the management of the pondok. Inspired by his educational experiences overseas, he transformed the pondok into Sekolah Menengah Ugama Darul Anuar (SMUDA), which is a more formal institution than a pondok. Nik Abdul Aziz managed the madrasah for many years before deciding to get involved in politics by joining PAS in 1967 and winning an election for the state legislative seat in 1969 (Warnk, 2008). Observers such as Farish Noor and Peter R. Riddel argue that Nik Aziz's admiration for the Deoband educational environment led him to a new political path of Islamism. He promoted "Islamic purification" and fought against "traditional practices, deviations and innovations" (Lee, 2017; Riddell, 2009: 185).

After 1969, much of his time was devoted to politics and the madrasah was entrusted to a state agency, Yayasan Islam Kelantan, in the 1970s. Nik Aziz's political career improved; in 1990, his party (PAS) won significant seats in Kelantan and he was appointed as the Chief Minister of Kelantan (Noor, 2004, 2008; Shiozaki, 2009; Yuki, 2013). His political actions were largely characterized by efforts to counter UNMO's political vision and promote "the implementation of Shari'a and opposition to secularism" (Riddell, 2009: 186). His opposition to UMNO's political policies and his Islamic political views conveyed him to the top level of his political career and provided him with the opportunities to bring what Riddle has termed "Shari'a- 
mindedness" to Malaysian politics (Riddell, 2009).

As a politician, Nik Abdul Aziz was instrumental in designing the state budget for madrasahs to be channeled to the Yayasan Islam Kelantan/YIK (Kelantan Islamic Foundation). As described by Farish Noor, who studied the connections between pondok and politics in Malaysia, the PAS-led government was committed to supporting pondok by allocating a significant amount of the state budget to these institutions. In 1991, the government spent 15 million Ringgit to support pondok schools, standardize Islamic education, and improve capacity building (Noor, 2008: 207). Efforts to increase the capacity of Islamic education in Kelantan was fruitful, as indicated by an increase in students studying in pondoks sponsored by YIK. Concerning the government policies on Islamic education, an observer, Tayeb Azmil, notes:

The capacity to disburse resources to financially struggling Islamic schools is another vital reason why the central government has been able to wield so much influence over Islamic education in Malaysia...Having financial prowess allows the federal government to absorb more resource-poor Islamic schools such as SAR under the management of the Ministry of Education and convert these schools into SABK. (Tayeb, 2018: 68)

He further emphasizes:

Even in Kelantan, known for its fierce pride in local traditions of Islamic learning, the Ministry of Education had managed to sign a memorandum of understanding (MoU) with the Kelantan Islamic Foundation (Yayasan Islam Kelantan, YIK) in 2008 to gain partial control over twenty hitherto autonomous yet financially struggling 
SAR (Utusan Malaysia, 13 August 2008). The dearth of resources, in short, creates a desperate sense of dependency among many Islamic schools and MAIN on the generosity and goodwill of the federal government (Tayeb, 2018: 68-69).

It appears that the experience of Maahad Darul Anuar was similar to that of other Islamic institutions in the 1970s. From the 1970s to 2008, it was under the control of the YIK. Maahad Darul Anuar might have profited from this by receiving extra facilities and infrastructure and having the teachers' salaries covered in full by the government. However, the conversion of the madrasah (now known as SMA Darul Anuar) was a complicated one. Even though it was built on property donated by the founder's family, the school did not bear the founder's name because the school is a waqf and can be handled freely by anybody who becomes a nazir (waqf manager). The pondok school system was unstructured when it first began. This pondok once served as a learning center for anyone interested in learning about Islam, regardless of age. When pondoks were in a precarious situation in the 1970s, the Kelantan government offered to subsidize certain utilities, and the madrasah representenative accepted. As a result, the madrasah progressed significantly. The number of pupils multiplied and the building was able to accommodate 1,200 students in a single year. In conclusion, Maahad Darul Anuar was led and managed by respected personalities such as Nik Abdul Aziz whose influence can be seen in the religious lives of Muslim communities and government policies in Kelantan. However, the school does not automatically 
obtain privileged from the community as trust in Islamic educational institutions does not depend on the political orientation of its founders.

\section{Resolving Financial Burdens: Two Different Paths}

\section{Pondok Lubok Tapah: "We Kept Our Autonomy to Preserve the Legacy"}

Our conversations with the officials and representatives of Pondok Lubok Tapah suggest that the pondok is not financially secure. As a private madrasah, Pondok Lubok Tapah is struggling to finance its operational costs. It cannot escape the financial burden. The position of Kelantan as an "Islamic state" does not guarantee that a private madrasah can gain sufficient financial support from the state. In Pondok Lubok Tapah, the teachers, both asatidz (male teachers) and asatidzah (female teachers) are paid solely by the pondok, whose financial income from student tuition is minimal. Therefore, the pondok runs various income-generating educational and religious activities and attempts to implant an entrepreneurial spirit among the teachers and administrators.

To provide a comparison, the businesses run by Pondok Lubok Tapah are not as large in scale as the businesses run by some pesantren in Indonesia, such as Pesantren Sidogiri in East Java, Pesantren Darussalam Gontor in Ponorogo-East Java, and Pesantren Nurul Iman in Bogor. Based on our visit and observations, these three pesantren have run businesses in various sectors, ranging 
from Islamic loan cooperatives (Baitul Mal wa al-Tamwil), agricultural products, Islamic fashion, culinary products, animal husbandry, fisheries, music entertainment, etc. (site visit in July 2019). Entrepreneurial projects have been utilized to modernize the Islamic financing system in order to cover pesantren's operational needs (Isbah, 2012). The sustainability of these three pesantrens is reliant upon modern management and entrepreneurial innovation.

It appears that the latest generation of Pondok Lubok Tapah leaders have realized that financial support from the government in Kelantan does not secure the school's financial needs. Therefore, entrepreneurial innovation is needed. In Lubok Tapah, the current leaders, represented by two children of Haji Abdullah, have taken the initiative to seek financial support by establishing supporting institutions. Dr. Luqman and his brother, Mr. Hamdan, set up the Akademi Tuan Guru Haji Abdullah Sdn Bhd, an institution whose duty is to preserve the legacy of their parents. This institution also functions as a special unit to seek and receive financial support from third parties, including private companies.

Dr. Luqman and Hamdan were drawn to entrepreneurship. In 2017, they established a private company called "Hayyan Group" (Hayyan DynamicSolution) which focuses on trading services. In the beginning, the company launched goat milk as its main product. Now, the company has expanded into the production and sale of culinary products. Pondok Lubok Tapah also started a Hajj and Umrah travel agency named Retaj Travel 7 Tours SDN BHD. This travel agency was warmly received by the 
Muslim community in Kelantan. The revenue from these companies has met the financial needs of Pondok Lubok Tapah. Although there are opportunities for support through the government's financial scheme, Pondok Lubok Tapah remains persistent in its position as a traditional pondok that can autonomously preserve its traditions and the legacy of its founder.

\section{Pondok Maahad Darul Anuar: "We Finally Relinquished Ownership"}

Conflicting views and differing perspectives among the family members on how to grow the reputation of Maahad Darul Anuar have spurred heated discussion and controversy among teachers and government representatives. Nik Omar, the leader of the madrasah from 2008-2018, had his own strategy for managing the school. He placed the strongest students in one class and gave them special training. Other students with ordinary academic abilities were placed in other categories and received different treatment and training.

This strategy resulted in a high level of student achievement, which in turn served as a promotion for the pondok. Every year, some students from the school won awards in various student competitions. However, despite these achievements, many teachers did not support the approach adopted by Nik Omar. They argued that because the pondok was under the supervision of the state, there was no reason to discriminate against students by placing them in different classes based on their academic ability (Interview July 2019). The state 
informed Nik Omar to change his policy, and the state, represented by Yayasan Islam Kelantan, replaced Nik Omar with another administrator, Nik Hamdi Abdul Ghani, the grandson of Nik Abdul Aziz.

Faced with this situation, Nik Omar Nik Omar made a decisive move. He wanted to withdraw the pondok from the state's supervision and turn it back into a private school. He argued that he could not implement his vision of elevating the pondok's reputation under state supervision. His father, Datok Guru or Nik Abdul Aziz, agreed with Nik Omar's decision. In 2008, it was announced the the pondok was becoming a private school again and was detaching from Yayasan Islam Kelantan. All teachers were then required to adopt the roles formulated by Nik Omar. However, other teachers, parents, and some of his family members did not support Nik Omar's decision, as they wanted the school to remain a state-funded school instead of a private madrasah. The teachers resisted because they were concerned about their future. They believed that, unlike a state school, a private school could not guarantee their salaries in the future. Therefore, some teachers resigned, and some parents withdrew their children from the school and enrolled them in other Islamic schools.

In 2009, the school's first year as a private school, the madrasah had 300 students but was only supported by two teachers. Therefore, the madrasah had no choice but to invite many teachers with little teaching experience. The teachers were paid entirely from the madrasah funds, which were sourced from tuition fees. This arrangement lasted for the first three years, from 
2010 to 2012, as the school continued to struggle with its management and financial issues. However, in the following years, starting in 2013, the madrasah faced severe financial constraints as the numbers of students decreased, and only part-time hours were available for teachers. The tuition fee was increased from RM 300 to RM 500 per month to resolve the financial issue. Thus, only students from upper-middle-class families could afford to study in the madrasah. The teachers were paid irregularly. Sometimes they received their wages two months late because of the financial crisis (Interview, July 2019). Families living near Pondok Maahad Darul Anuar preferred to enroll their children in other madrasahs with more affordable tuition fees even though these schools were further from their homes. Nik Omar attempted to resolve the financial crisis by establishing cooperatives and some other businesses, such as homestays and stores, but these businesses were not able to resolve the financial problems.

This delicate situation drew the attention of the community and the family members of Darul Anuar's founder. Communities around the madrasah were disappointed with Darul Anuar's management decision. They complained that they had supported the madrasah with the understanding that it would be a school for the whole community, not only for affluent families. Other children of Datok Guru paid serious attention to these complaints and requested that the madrasah reverse its decision. Datok Guru passed away in 2015, and in the next year, in 2016, sixteen children of Datok Guru agreed to transform the madrasah back into a state- 
funded school (Interview with Nik Hamdi Abul Ghani, July 2019). They negotiated with Nik Omar, who refused to change his mind about about the madrasah remaining a private school. Then, in 2018, the school was "returned" to the state, becoming a state-funded madrasah after ten years of private ownership. Maahad or SMA Darul Anuar is one example of an Islamic school in Kelantan that was founded as a Sekolah Agama Rakyat (SAR, People Religious School) and then transformed into a Sekolah Menengah Agama Negeri (State-based Religious School).

\section{E. Conclusion}

For private Islamic schools or Sekolah Agama Rakyat (SAR) facing financial difficulties, it is not easy to predict their future trajectories regarding institutional management and the preservation of school traditions, especially in a country where politics and Islam are tightly intermingled. The social, economic, and political situation in Kelantan reveals that although Islam heavily influences the state, not all Islamic schools, including pondoks, can develop their institutions and preserve their legacies without difficulty. The financial constraints experienced by some Islamic schools as a result of their management decisions can have significant consequences. In the Malaysian context, including in Kelantan, the government may only have two choices: provide limited support to the schools or convert private Islamic schools into state-funded schools. The fact is that some communitybased Islamic schools or madrasah have chosen the more "promising" option, which is to transform their private schools into government schools. Other Islamic schools attempt to survive by becoming self-funded and considering 
other financial resources to preserve their institutions.

Pondok Lubok Tapah and SMA Darul Anuar are two examples of madrasah in Malaysia that have attempted to escape from their financial constraints. In the past, these two schools were led by prominent and respected 'ulamas in Kelantan. Pondok Lubok Tapah was led by a renowned 'ulama, Tuan Guru Haji Abdullah, while SMA Darul Anuar was chaired by a prominent 'ulama cum politician in Kelantan, Tuan Guru Nik Abdul Aziz. The reputation of these two respected 'ulamas has helped these institutions become choice schools for students in the surrounding community and other regions in Kelantan and even outside the state. However, this reputation does not always fit with the current financial needs of the schools, which operate in a religious, economic, and political environment that has changed over time. It appears that Pondok Lubok Tapah has preserved its traditional pondok system by focusing on learning Islam as well as Islamic turath.

The teachers in Pondok Lubok Tapah understand the importance of maintaining the Islamic legacy introduced by the founder and his family. The experience of SMA Darul Anuar is different. For this madrasah, becoming a state funded-school has meant following all officially accepted systems introduced by the government, represented by Yayasan Islam Kelantan. The modernization and standardization of its curriculum is the cost that the school must pay to receive government financing for its activities. The results are twofold: Pondok Lubok Tapah only receives minimal support from the government, but the pondok is still able to keep its autonomy and legacy as a waqffunded school; on the other hand, Madrasah Darul Anuar receives more support from the government, but has had to relinquish its ownership to state agencies. 


\section{References}

Abdullah, M., Samsudin, M. A., \& Yahaya, M. Z. (2011). Pemikiran Fiqh Tuan Guru Haji Abdullah Lubok Tapah. In A. F. Kamaruzzaman, E. A. Jamsari, \& E. A. Rozali (Eds.), Prosiding Nadwah 'ulama Nusantara (NUN) IV: 'ulama Pemacu Transformasi Negara (pp. 334-344). Bangi: Jabatan Pengajian Arab dan Tamaddun Islam, Fakulti Pengajian Islam, University Kebangsaan Malaysia.

Ahmad, R., Albasri, S. H., Arsad, S., \& Said, R. (2019). A Critical Analysis of Zakat and Waqf in Sustaining the Development and Survival of Pondok Institution in Kedah. In Islamic Development Management. https:// doi.org/10.1007/978-981-13-7584-2_17

Alfurqan, A. (2020). Evolution and Modernization of Islamic Education In Minangkabau. Afkaruna, 16(1), 82-99. https://doi.org/10.18196/aiijis.2020.0114.82-98

Ali, M. (2006). Transmission of Islamic Knowledge in Kelantan. Journal of the Malaysian Branch of the Royal Asiatic Society, 79(2), 39-58.

Arifin, A. Z. (2013). Charisma and Rationalisation in a Modernising Pesantren: Changing Values in Traditional Islamic Education in Java. Ph.D. Thesis, University of Sydney. http://researchdirect.uws.edu.au/islandora/ object/uws\%3A17130/

Azra, A. (2004). The Origin of Islamic Reformism in Southeast Asia: Networks of Malay-Indonesian and Middle Eastern 'ulama in the Seventeenth and Eighteenth Century. Honolulu: Hawai'i University Press.

Brooks, M. C. (2015). School principals in Southern Thailand: Exploring trust with community leaders during conflict. 
Educational ManagementAdministration and Leadership, 43(2). https://doi.org/10.1177/1741143213513191

Brooks, M. C., Brooks, J. S., Mutohar, A., \& Taufiq, I. (2020). Principals as socio-religious curators: progressive and conservative approaches in Islamic schools. Journal of Educational Administration, 58(6), 232-252. https:// doi.org/10.1108/JEA-01-2020-0004

Dhofier, Z. (1990). Traditional islamic education in the malav archipelago: Its contribution to the integration of the malay world. Indonesia Circle. School of Oriental \& African Studies. Newsletter, 19(53), 19-34. https://doi. org/10.1080/03062849008729746

Fathil, F., \& Oktasari, W. (2017). Religious Education and Containment of Radical Elements: the Case of Pondok Schools in Malaysia. UMRAN - International Journal of Islamic and Civilizational Studies, 4(1-1), 60-70. https://doi.org/10.11113/umran2017.4n1-1.205

Fazial, F., \& Bahari, Z. (2018). Problems Faced By the Pondok Institutions in Funding Development. International Journal of Academic Research in Business and Social Sciences, 8(6). https://doi.org/10.6007/ijarbss/v8i6/4536

Gazali, H. M., \& Che Ismail, C. M. H. (2019). A Conceptual Framework for Cash Waqf with Blockchain in Financing Education for the Islamic Religious School in Malaysia. Al-Itqan: Journal of Islamic Sciences and Comparative Studies, 3(1), 73-88.

Hashim, C. N., \& Langgulung, H. (2008). Islamic Religious Curriculum in Muslim Countries: The Experiences of Indonesia and Malaysia. Bulletin of Education \& Research, 30(1), 1-9. 
Hashim, R., Rufai, S. A., Roslan, M., \& Nor, M. (2011). Traditional Islamic Education in Asia and Africa: A Comparative Study of Malaysia's Pondok, Indonesia's Pesantren and Nigeria's Traditional Madrasah. World Journal of Islamic History and Civilization, 1(2), 94-107.

Hefner, R. W. (2007). Schooling Islam: The Culture and Politics of Modern Muslim Education (R. W. Hefner \& M. Q. Zaman (eds.)). Princeton: Princetton University Press.

Huwaida, H. (2015). Change and Development in the Acehnese Dayah Salafi (a Case Study). Jurnal Ilmiah Peuradeun, 3(2), 279-294. https://journal.scadindependent.org/ index.php/jipeuradeun/article/view/67

Isbah, M. F. (2012). Religiously committed and prosperously developed: The survival of pesantren salaf in modern Indonesian Islamic education. RIMA: Review of Indonesian and Malaysian Affairs, 46(1), 83-104.

Isbah, M. F. (2019). How is Social Capital Coverted to be Economic Capital? A Case Study from Pesantren's Socio Economic Projects. Al-Izzah: Jurnal Hasil-Hasil Penelitian, 14(1), 18-35. https://doi.org/10.31332/ ai.v14i1.1240

Jamsari, E. A., \& Zain, F. M. (2006). Peranan dan Sumbangan Tuan Guru Haji Abdullah bin Haji Abdul Rahman dalam Perkembangan Pendidikan Islam di Kelantan. Prosiding Nadwah 'ulama Nusantara III Ketokohan Dan Pemikiran 'ulama Melayu, 198-212.

Latief, H, \& Amirrachman, A. R. (2016). Islamic philanthropy and the rights to education: Modalities of education provision for underprivileged groups in Indonesia. In Educating Marginalized Communities in East and Southeast Asia: State, Civil Society and NGO 
Partnerships. London: Routledge, 37-52. https://doi. org/10.4324/9781315561998

Latief, Hilman. (2012). Filantropi Islam dan Aktivisme Sosial Berbasis Pesantren. Afkaruna: Jurnal Ilmu-Ilmu Keislaman, 8(2), 188-201. https://doi.org/10.18196/ AIIJIS.2012

Leirvik, O. (2004). Religious education, communal identity and national politics in the Muslim world. British Journal of Religious Education, 26(3), 223-236. https:// doi.org/10.1080/0141620042000232283

Liow, J. C. (2009). Piety and Politics: Islamism in Contemporary Malaysia. In Piety and Politics: Islamism in Contemporary Malaysia. https://doi.org/10.1093/ acprof:oso/9780195377088.001.0001

Mahmud, A. R. (2017). Biografi Singkat 40 'ulama Terpilih Negeri Kelantan. Kota Bharu: Majlis Agama Islam dan Adat Istiadat Melayu Kelantan.

Malami, H. U. (1993). Financing Islamic education in Muslim minority states: the case of Nigeria. Institute of Muslim Minority Affairs. Journal, 14(1-2). https://doi. org/10.1080/13602009308716276

Mohd. Ramli, F. Z., Abdul Majid, L., \& Nazri, M. A. (2017). Faktor Dorongan Persambungan Sanad Kitab Hadis dalam Pengajian Talaqqi Bersanad di Malaysia. UMRAN - International Journal of Islamic and Civilizational Studies, 4(1). 13-26. https://doi.org/10.11113/ umran2017.4n1.117

Mujani, W. K., Mohd Taib, M. S., \& Yaakub, N. I. (2014). Educational Waqf (Islamic Endowment) in Malaysia, 117-120. 2nd International Conference in Humanities, Social Sciences and Global Business Management. 
Noor, F. A. (2004). Islam Embedded: The Historical Development of the Pan-Malaysian Islamic Party (PAS), 1951-2003. Kuala Lumpur: Malaysian Sociological Research Institute (MSRI).

Noor, F. A. (2008). 7. From Pondok to Parliament: The Role Played by the Religious Schools of Malaysia in the Development of the Pan-Malaysian Islamic Party (PAS). In In F. A. Noor, Y. Sikand, \& M. van Bruinessen (Eds.), The Madrasa in Asia: political activism and transnational linkages. Amsterdam: Amsterdam University Press, 191216. https://doi.org/10.1515/9789048501380-009

Noor, F. A., Sikand, Y., \& Bruinessen, M. van. (2008). Introduction: Behind the Walls: Re-Appraising the Role and Importance of Madrasas in the World Today. In F. A. Noor, Y. Sikand, \& M. van Bruinessen (Eds.), The Madrasa in Asia Political Activism and Transnational Linkages. Amsterdam University Press.

Pohl, F. (2006). Islamic education and civil society: Reflections on the pesantren tradition in contemporary Indonesia. In Comparative Education Review (Vol. 50, Issue 3), 389409. https://doi.org/10.1086/503882

Riddell, P. G. (2009). Shari'a-Mindedness in the Malay World and the Indian Connection: The Contributions of Nur alDin al-Raniri and Nik Abdul Aziz bon Haji Nik Mat. In M. Feener \& T. Sevea (Eds.), Islamic Connections: Muslim Societies in South and Southeast Asia. Singapore: ISEAS, 175-194.

Roche, S. (2012). Dayah, the Traditional Islamic Education System of Aceh 1900-2000. Media Syariah, 14(2), 239250. 
Shiozaki, Y. (2009). The State and 'ulama in Contemporary Malaysia. In State, Society and International relations in Asia. Amsterdam: Amsterdam University Press, 95-104.

Steenbrink, K. A. (1986). Pesantren, Madrasah, Sekolah. Jakarta: LP3ES.

Steiner, K. (2011). Madrasah in Singapore: Tradition and modernity in religious education. Intellectual Discourse, 19(1), 41-70.

Tayeb, A. (2018). Islamic Education in Indonesia and Malaysia. In Islamic Education in Indonesia and Malaysia. https:// doi.org/10.4324/9781351116862

Tayeb, A. (2019). Federalism in Serambi Mekah: Management of Islamic Education in Kelantan. In L. Sophie (Ed.), Illusions of Democracy: Malaysian Politics and People. Amsterdam: Amsterdam University Press, 63-77.

Warnk, H. (2008). 'Why Are They So Afraid of Islam?' Nik Abdul Aziz Nik Mat, Abdul Hadi Awang und Nicht-Muslime in Malaysia'. In Religion und Identität. Muslime und NichtMuslime in Södostasien (pp. 137-159). Harrassowitz (= Frankfurter Forschungen zu Södostasien 4).

Winzeler, R. L. (2017). Traditional Islamic School in Kelantan. Journal of the Malaysian Branch of the Royal Asiatic Society, 48(1), 91-103.

Yuki, S. (2013). The Dilemma of 'ulama in Malaysia: The Controversy on Kafir Declaration and Official Fatwas between UMNO and PAS in the 1980s. Southeast Asia: History and Culture, 2013(42), 5-31. https://doi. org/10.5512/sea.2013.42_5 
Zarkasyi, H. F. (2020). Imam Zarkasyi's modernization of pesantren in Indonesia: (A case study of darussalam gontor). Qudus International Journal of Islamic Studies, 8(1), 161-200. https://doi.org/10.21043/QIJIS. V8I1.5760

\section{Websites}

https://www.bharian.com.my/berita/wilayah/2018/10/ 484268/yik-ambil-alih-maahad-darul-anuar-tahundepan

https://www.malaysiakini.com/news/458490

https://www.bharian.com.my/berita/wilayah/2019/01/ 516057/nik-omar-ikrar-rampas-semula-darul-anuar

https://www.bharian.com.my/berita/wilayah/2018/12/ 507838/jangan-ganggu-mada-nik-omar 